\title{
Implementasi Usability Testing dalam Evaluasi Website Sekolah
}

\author{
Studi Kasus: SMK Negeri Sumsel
}

\author{
Susan Dian Purnamasari ${ }^{[1]}$, Firamon Syakti ${ }^{[2]^{*}}$ \\ Fakultas Ilmu Komputer ${ }^{[1],[2]}$ \\ Universitas Bina Darma \\ Palembang, Indonesia \\ susandian@binadarma.ac.id ${ }^{[1]}$, firamon@binadarma.ac.id ${ }^{[2]}$
}

\begin{abstract}
One of the products of information technology that is common today is the school website. Where the school website is the spearhead for schools in disseminating information to related parties. The most important aspect of a website is the usability aspect because it greatly affects visitor convenience. The use of the website for disseminating information is also used by SMK Negeri Sumsel and the school's main portal on the internet. For that to see the importance of the usability aspect, this study aims to see the level of usability of the SMK Negeri Sumsel website. In measuring the level of usability, usability testing techniques are used with the stages of preparation, selecting respondents, data collection and data analysis. The test results show that the usability aspects on the website such as errors, learnability, memorability and satisfaction get good ratings while the efficiency aspects are not categorized as good.
\end{abstract}

\section{Keywords-Usability Testing, Website, SMK Negeri Sumsel}

\begin{abstract}
Abstrak - Salah satu produk dari teknologi informasi yang umum saat ini adalah website sekolah. Dimana website sekolah merupakan ujung tombak bagi sekolah dalam menyebarkan informasi kepada pihak terkait. Aspek yang terpenting dalam sebuah website adalah aspek usability karena sangat mempengaruhi kenyamanan pengunjung. Penggunaan website untuk penyebaran informasi juga digunakan oleh SMK Negeri Sumsel dan portal utama sekolah di internet. Untuk itu melihat pentingnya aspek usability maka pada penelitian ini bertujuan untuk melihat tingkat usability dari website SMK Negeri Sumsel. Dalam melakukan pengukuran tinggat usability digunakan teknik usability testing dengan tahapan persiapan, memilih responden, pengumpulan data dan analisis data. Hasil pengujian menunjukkan bahwa aspek usability pada website seperti error, learnability, memorability dan satisfaction mendapatkan penilaian baik sedangkan pada aspek efficiency belum dikategorikan baik.
\end{abstract}

Kata Kunci-Usability Testing, Website, SMK Negeri Sumsel

\section{PENDAHULUAN}

Perkembangan tekhnologi informasi saat ini semakin meningkat, perkembangan tersebut dapat mencakup tekhnologi elektronika, informasi, dan telekomunikasi seperti satelit, komputer, internet dan sebagainya, Kemajuan tekhnologi tersebut patut kita syukuri, karena dengan hadirnya tekhnologi berbagai pemenuhan kebutuhan hidup manusia menjadi lebih mudah bahkan kemajuan tekhnologi menjadi bukti perkembangan kemampuan manusia untuk menggunakan nalar dan pikirannya dalam mengolah alam dan potensi diri manusia itu sendiri dan hal ini mempunyai pengaruh yang positif terhadap lalulintas barang, jasa, investasi, informasi dari satu negara ke negara lainnya. Kebutuhan akan informasi data pun semakin berkembang seiring semakin mudahnya seorang menerima serta merespon suatu informasi komunikasi. Proses tersebut menimbulkan suatu kebutuhan untuk mengakses data, salah satunya adalah internet. Internet merupakan media untuk membawa informasi, sedangkan daya guna yang bisa dimanfaatkan adalah informasi yang ada di dalamnya.

Perkembangan Teknologi Internet yang pesat telah memicu munculnya berbagai aplikasi baru termasuk di bidang Teknologi Informasi. Website adalah salah satu revolusi dibidang informasi berbasis teknologi Internet [1]. Website diharapkan dapat dijadikan alternatif bagi pengembangan system informasi yang lebih efektif dan efisien dengan biaya yang lebih rendah dimasa mendatang. Hal ini dapat berjalan lancar apabila ada suatu jaringan komputer. Dengan adanya website diharapkan dapat membantu masyarakat pada umumnya dan sekolah pada khususnya untuk melakukan penyebaran informasi dengan cepat, murah dan efektif. Seiring dengan perkembangan tekhnologi informasi website bukan lagi sekedar menawarkan company/product profile melainkan menuju ke system back office (pengelolahan sistem perkantoran/instansi/sekolah) secara online dan realtime [2].

Sistem informasi sekolah berbasis website merupakan implementasi system back office yang berbasis website [3]. Sekolah adalah tempat pendidikan dimana siswa dan guru melakukan kegiatan Belajar Mengajar (KBM), dalam hal ini sekolah (SMK Negeri Sumsel Palembang) dapat memberikan informasi sekolahnya kepada orang yang membutuhkan informasi khususnya orang tua siswa, siswa maupun masyarakat sekitar. SMK Negeri Sumsel Palembang merupakan salah satu sekolah yang sudah memanfaatkan website sebagai sarana informasi dan komunikasi secara online. Website SMK Negeri Sumsel ini membahas mengenai 
profil Website Negeri Sumsel dengan jelas. Selain itu, terdapat informasi-informasi tentang sekolah yang akan memberikan penjelasan kepada kita mengenai aktivitas maupun event, serta beberapa informasi berita yang terjadi dalam waktu dekat ini. Semua ini diharapkan dapat memberikan informasi kepada masyarakat mengenai website SMK Negeri Sumsel Palembang, akan tetapi saat mencari dan menemukan data yang diinginkan pada website ini belum banyak informasi yang diberikan secara jelas dan dirasa sulit dalam mengakses untuk menemukan data informasi tersebut. Maka website SMK Negeri Sumsel Palembang perlu di evaluasi kemanfaatannya (Usability Testing).

Kajian terkait dengan usability telah banyak dilakukan diantaranya adalah pengujian usability untuk aplikasi simalu yang berkaitan dengan kebersihan [4] dan juga pengujian website pondok pesantren [5]. Kedua kajian tersebut dilakukan pengujian dengan teknik dan isntrumen yang berbeda yaitu system usability scale. Sehingga jika dibandingkan dengan penelitian yang dilakukan terdapat perbedaan pada cara melakukan pengujian usability. Dimana proses penelitian yang dilakukan denan lima variabel yang terdiri dari usability, learnability, satisfaction, efficiency, memorability dan error.

Untuk itu peneliti akan melakukan menguji usability beberapa aspek yang meliputi dari aspek learnability, efficiency, memorability, errors, dan satisfaction [6]. usability testing ini berkaitan dengan website SMK Sumsel dengan menggunakan metode tools otomatis dan evaluasi berbasis kuisioner dengan parameter kepuasan pengguna. Kuesioner merupakan penyebaran kuesioner yang terstruktur dimana reseponden sebagai target dapat menyelesaikan tugas melalui internet. Untuk memasukkan data pengguna menggunakan formulir. Selanjutnya dilakukan analisis sehingga menghasilkan informasi. Pada saat melakukan survei, pengguna mendapat kesempatan untuk mempelajari apa yang ingin dicapai dan informasi apa yang dicari oleh pengguna.

\section{METODOLOGI PENELITIAN}

\section{A. Prosedur Penelitian}

Dalam melakukan penelitian pengujian usability maka prosedur penelitian dalakukan sesuai dengan teori yang ada pada usability yaitu: "Planning A Usability Test, Selecting a representative sample and recruiting participants, Preparing the test materials and actual test environment, Conduction the usability test, Debriefing the Participant, Analyzing the data of the usability test, Reporting the result and making recommendations to improve the design and effectives of the product" [7] seperti yang diperlihatkan pada Gambar 1.

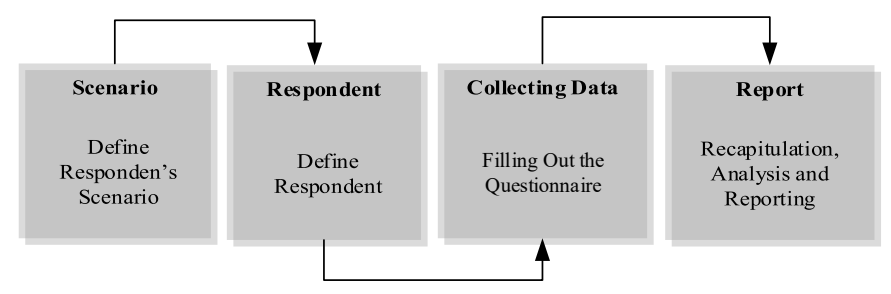

Gambar 1. Proses Pengujian Usability [8]

Dari pernyataan tersebut maka dapat dijelaskan prosedur penelitian yang dilakukan yaitu sebagai berikut [9]:

- Memilih Objek Penelitian, langkah ini adalah proses penentuan objek yang akan diteliti yaitu, website SMK Negeri Sumsel Palembang.

- Memilih responden untuk melakukan pengisian kuisioner seperti pada Tabel 1 berdasarkan jumlah sampel yang telah ditentukan.

- Mempresentasikan tugas kepada responden, langkah ini adalah memberikan penjelasan kepada responden bahwa yang diuji bukan responden tetapi objek penelitian dan memberikan penjelasan bagaimana proses mengisikan kuisioner.

- Memberikan tugas kepada responden, yaitu memberikan tugas-tugas dalam kuisioner untuk dijawab oleh responden

- Pengisian kuisioner dari responden, responden memberikan jawaban untuk kuisioner yang diberikan sesuai dengan yang dialami oleh responden.

- Analisa jawaban dari responden terhadap website dari segi jawaban responden

- Dari evaluasi yang dilakukan akan mendapatkan informasi yang lengkap mengenai kelebihan dan kekurangan website yang sekarang ini ada mengunakan teknik usability testing.

- Membuat laporan dari evaluasi dan memberikan rekomendasi.

TABLE I. DAFTAR PERTANYAAN USABILITY TESTING [10]

\begin{tabular}{|l|l|l|}
\hline \multicolumn{2}{|c|}{ Komponen Pertanyaan } & Jawaban \\
\hline \multicolumn{2}{|c|}{ Usability } & Ya / Tidak \\
\hline 1. & $\begin{array}{l}\text { Apakah anda dapat mengakses link website SMK } \\
\text { Negeri Sumsel dengan mudah? }\end{array}$ & Ya / Tidak \\
\hline 2. & $\begin{array}{l}\text { Apakah website SMK Negeri Sumsel mudah } \\
\text { digunakan dengan baik? }\end{array}$ & Ya / Tidak \\
\hline 3. & $\begin{array}{l}\text { Apakah website sekolah SMK Negeri Sumsel } \\
\text { merupakan alat bantu dalam proses belajar mengajar }\end{array}$ & Ya / Tidak \\
\hline Learnability mudah? & $\begin{array}{l}\text { Apakah anda dapat mengakses link website SMK } \\
\text { Negeri Sumsel dengan mudah? }\end{array}$ & Ya / Tidak \\
\hline 1. & $\begin{array}{l}\text { Apakah anda dapat mencari informasi dan } \\
\text { pengumuman yang diinginkan dengan mudah? }\end{array}$ & Ya / Tidak \\
\hline 3. & $\begin{array}{l}\text { Dapatkah anda menemukan profil informasi sekolah } \\
\text { SMK Negeri Sumsel pada website tersebut? }\end{array}$ & Ya / Tidak \\
\hline 4. & $\begin{array}{l}\text { Dapatkah anda menemukan link kontak admin sekolah } \\
\text { SMK Negeri Sumsel pada website? }\end{array}$ \\
\hline
\end{tabular}




\begin{tabular}{|c|c|c|}
\hline 5. & $\begin{array}{l}\text { Bisakah anda menemukan menu home pada website } \\
\text { SMK Negeri Sumsel? }\end{array}$ & Ya / Tidak \\
\hline \multicolumn{3}{|c|}{ Satisfaction } \\
\hline 1. & $\begin{array}{l}\text { Apakah tampilan website SMK Negeri Sumsel sangat } \\
\text { menarik untuk dikunjungi? }\end{array}$ & Ya / Tidak \\
\hline 2. & $\begin{array}{l}\text { Apakah anda merasa puas dengan fungsi } \\
\text { pencarian/search yang ada di website SMK Negeri } \\
\text { Sumsel Palembang? }\end{array}$ & Ya / Tidak \\
\hline 3. & $\begin{array}{l}\text { Apakah anda sangat tertarik untuk mengakses } \\
\text { menggunakan website SMK Negeri Sumsel? }\end{array}$ & Ya / Tidak \\
\hline 4. & $\begin{array}{l}\text { Dapatkah anda memahami tampilan menu di website } \\
\text { SMK Negeri Sumsel kembali? }\end{array}$ & Ya / Tidak \\
\hline 5. & $\begin{array}{l}\text { Apakah anda merasa nyaman dan ingin mengunjungi } \\
\text { website SMK Negeri Sumsel kembali? }\end{array}$ & Ya / Tidak \\
\hline \multicolumn{3}{|c|}{ Efficiency } \\
\hline 1. & $\begin{array}{l}\text { Apakah anda menemukan link home pada website } \\
\text { SMK Negeri Sumsel dengan cepat? }\end{array}$ & Ya / Tidak \\
\hline 2. & $\begin{array}{l}\text { Apakah anda melakukan proses search pencarian } \\
\text { informasi dengan cepat pada website SMK Negeri } \\
\text { Sumsel? }\end{array}$ & Ya / Tidak \\
\hline 3. & $\begin{array}{l}\text { Apakah anda dapat melakukan login dengan cepat } \\
\text { pada menu login di website SMK Negeri Sumsel? }\end{array}$ & Ya / Tidak \\
\hline 4. & $\begin{array}{l}\text { Dapatkah anda menemukan link berita dan } \\
\text { Pengumuman berita terupdate tiap hari dengan cepat? }\end{array}$ & Ya / Tidak \\
\hline 5. & $\begin{array}{l}\text { Apakah anda dapat kembali ke menu sebelumnya } \\
\text { dengan mudah dan cepat pada website SMK Negeri } \\
\text { Sumsel? }\end{array}$ & Ya / Tidak \\
\hline \multicolumn{3}{|c|}{ Memorability } \\
\hline 1. & $\begin{array}{l}\text { Dapatkah anda mengingat tampilan menu dan } \\
\text { informasi pada website SMK Negeri Sumsel? }\end{array}$ & Ya / Tidak \\
\hline 2. & $\begin{array}{l}\text { Apakah anda dapat mengingat link website SMK } \\
\text { Negeri Sumsel dengan mudah? }\end{array}$ & Ya / Tidak \\
\hline 3. & $\begin{array}{l}\text { Bisakah anda menemukan dan mengakses kembali } \\
\text { menu pengumuman pada website SMK Negeri } \\
\text { Sumsel? }\end{array}$ & Ya / Tidak \\
\hline 4. & $\begin{array}{l}\text { Bisakah anda menemukan dan mengakses kembali } \\
\text { menu sebelumnya pada website SMK Negeri Sumsel? }\end{array}$ & Ya / Tidak \\
\hline 5. & $\begin{array}{l}\text { Dapatkah anda menemukan informasi berita tentang } \\
\text { Sekolah kembali? }\end{array}$ & Ya / Tidak \\
\hline \multicolumn{3}{|c|}{ Error } \\
\hline 1. & $\begin{array}{l}\text { Bisakah anda mengakses website SMK Negeri Sumsel } \\
\text { dengan baik? }\end{array}$ & Ya/Tidak \\
\hline 2. & $\begin{array}{l}\text { Apakah anda menemukan informasi yang diinginkan } \\
\text { pada website SMK Negeri Sumsel dengan baik? }\end{array}$ & Ya / Tidak \\
\hline 3. & $\begin{array}{l}\text { Apakah anda dapat menelusuri menu search informasi } \\
\text { pada website SMK Negeri Sumsel dengan baik? }\end{array}$ & Ya / Tidak \\
\hline 4. & $\begin{array}{l}\text { Dapatkah anda mengakses setiap menu yang ada di } \\
\text { website SMK Negeri Sumsel dengan baik? }\end{array}$ & Ya / Tidak \\
\hline 5. & $\begin{array}{l}\text { Bisakah anda mengakses menu home page pada } \\
\text { website SMK Negeri Sumsel dengan baik? }\end{array}$ & Ya / Tidak \\
\hline
\end{tabular}

\section{B. Populasi dan Sampel}

Dalam evaluasi yang dilakukan terhadap situs website SMK Negeri Sumsel Palembang menggunakan Usability Testing diperlukan dari sebuah populasi. Populasi adalah sekumpulan orang, hewan, tumbuhan, atau benda yang mempunyai karakteristik tertentu yang akan diteliti. Populasi akan menjadi wilayah generalisasi kesimpulan dari hasil penelitian [11]. Sample yang diambil dari populasi adalah pengguna yang nantinya akan dijadikan responden dalam usability testing. Pengguna yang akan dijadikan sample harus mewakili dari seluruh populasi (pengguna) [12].

Jumlah total seluruh populasi warga SMK Negeri Sumsel sebanyak 398 orang, dimana populasi tersebut terdiri dari jumlah siswa sebanyak 329 orang, guru terdiri dari 57 orang dan staff pegawai 13 orang. Jumlah siswa perempuan nya sebanyak 42 orang dan laki-laki sebanyak 286. Dalam hal ini penulis akan menentukan sampel yang di ambil dari rumus slovin yaitu sebagai berikut [13], [14]:

$$
n=\frac{\mathrm{N}}{\mathrm{N} \cdot \mathrm{e}^{2}+1}
$$

$n=$ Jumlah sampel

$N=$ Jumlah populasi

$e^{2}=$ Presisi(ditetapkan 10\% dengan tingkat kepercayaan 95\%)

Maka penentuan jumlah sampel dapat dilakukan perhitungan seperti berikut ini:

$$
\begin{aligned}
& n=\frac{398}{398.0 .01+1} \\
& n=\frac{398}{4.98} \\
& n=79 / 100
\end{aligned}
$$

Untuk itu jumlah sampel yang digunakan dalam penelitian ini berjumlah 79 orang yang dibulatkan menjadi 80 orang. Sampel yang diambil dari populasi adalah pengguna yang nantinya akan dijadikan responden dalam usability testing. Pengguna yang akan dijadikan sampel harus mewakili dari seluruh populasi (pengguna).

\section{Objek Pengukuran}

Website yang dijadikan objek pengukuran usability testing adalah website sekolah SMK Sumsel yang beralamat pada http://smknsumsel.sch.id tampilan halaman utama website SMK Sumsel seperti yang diperlihatkan pada Gambar 2.

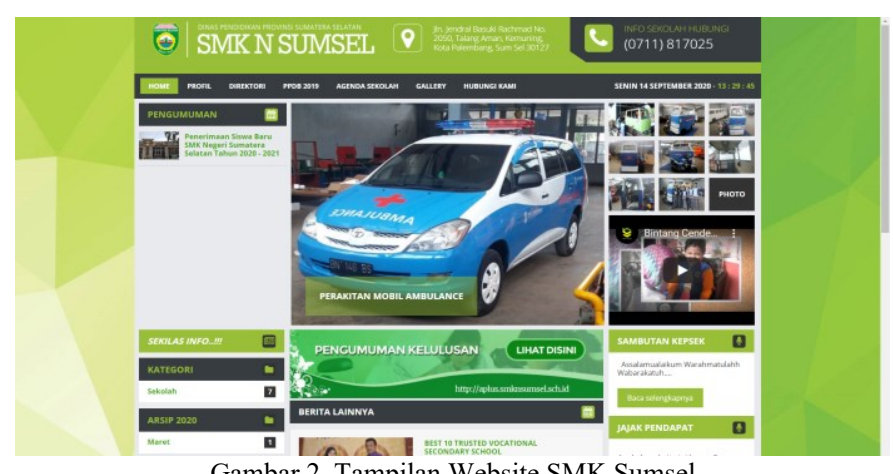

Gambar 2. Tampilan Website SMK Sumsel

\section{HASIL DAN PEMBAHASAN}

Setelah melakukan proses penelitian usability testing terhadap website SMK Sumsel maka hasil penelitian dapat dijelaskan sebagai berikut:

\section{A. Responden Penelitian}

Responden dalam penelitian ini yaitu guru, staff, dan siswa SMK Negeri Sumsel Palembang. Penyebaran kuisioner dilakukan menggunakan penyebaran secara langsung dan acak sebanyak 80 kuisioner didistribusikan kepada responden. Hasil dari penyebaran kuesioner selanjutnya diolah untuk di analisis. Karateristik responden dalam penelitian ini yaitu terdiri dari 
jenis responden, jenis kelamin, dan usia. Dari aspek jenis responden terdiri dari guru sebanyak 30 orang, Staff sebanyak 12 orang, dan Siswa sebanyak 38 orang seperti yang diperlihatkan pada Gambar 3.

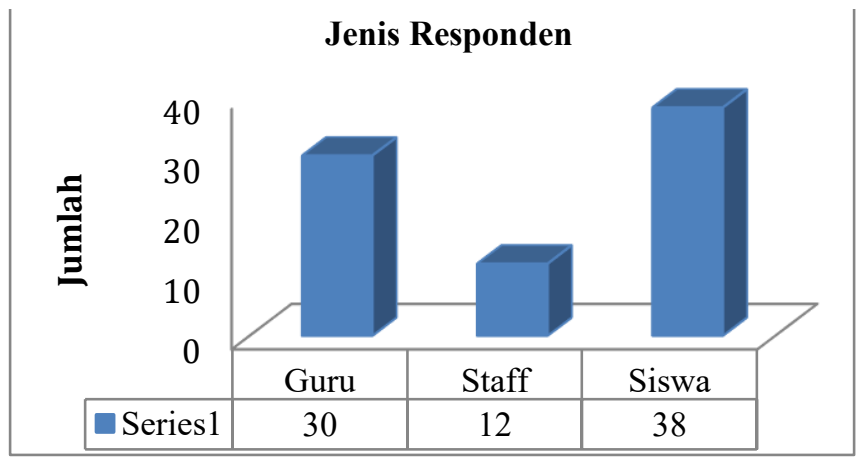

Gambar 3. Jenis Respoden

Selanjutnya adalah karateristik jenis kelamin, dimana responden terhadap website SMK Negeri Sumsel Palembang berdasarkan jenis kelamin terdiri dari $67 \%$ berjenis kelamin laki-laki berjumlah 54 orang, sedangkan responden berjenis kelamin perempuan berjumlah 26 orang atau sebesar $33 \%$.

\section{Jenis Kelamin Responden}

- Laki-Laki $\quad$ Perempuan

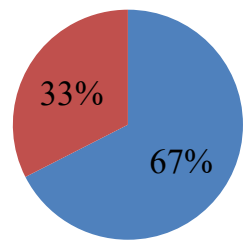

Gambar 4. Jenis Kelamin Responden

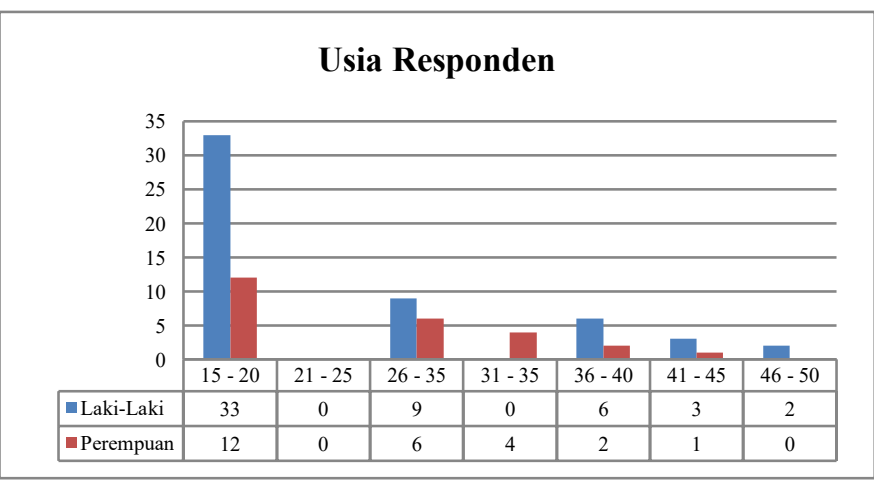

Gambar 5. Usia Responden

Sedangkan karateristik responden yang dilihat dari usia terdiri dari 12-20 tahun 25 responden, 26-35 tahun terdiri dari
15 responden, 31-35 tahun terdiri dari 4 orang, 36-40 tahun terdiri dari 8 responden, 41-45 tahun terdiri dari 4 responden dan 46-50 tahun terdiri dari 2 responden seperi yang diperlihatkan pada Gambar 5.

\section{B. Jawaban Responden}

Dari task bagaian "Formulir Uji Ketergunaan" yang diberikan kepada responden pada website SMK Negeri Sumsel maka dapat dilakukan rekapitulasi dari semua jawaban task yang dijawab oleh responden. Untuk itu berikut dapat dijelaskan jawaban yang diberikan oleh responden.

Aspek learnability seperti berikut ini:

- Apakah Anda dapat mengakses link website SMK Negeri Sumsel Palembang? Pada soal ini semua responden dapat menjawab pertanyaan dengan baik, dan masing - masing responden berhasil menjawab di bawah rata - rata waktu 5 detik.

- Apakah anda dapat mencari informasi dan pengumuman yang diinginkan dengan mudah? Pada soal di ini semua responden dapat menjawab pertanyaan dengan baik, dan masing - masing responden berhasil menjawab di bawah rata - rata waktu 10 detik.

- Dapatkah anda menemukan profil informasi sekolah SMK Negeri Sumsel Palembang pada website tersebut? Pada soal ini atas semua responden dapat menjawab pertanyaan dengan baik, dan masing masing responden berhasil menjawab hanya 5 detik.

- Dapatkah anda menemukan link kontak admin sekolah SMK Negeri Sumsel Palembang pada website? Pada soal di ini semua responden dapat menjawab pertanyaan dengan baik, dan masing - masing responden berhasil menjawab di bawah rata - rata waktu hanya 5 detik.

- Bisakah anda menemukan menu home pada website SMK Negeri Sumsel? soal ini atas semua responden dapat menjawab pertanyaan dengan baik, dan masing - masing responden berhasil menjawab di bawah rata - rata waktu hanya 10 detik

Aspek satisfaction seperti berikut ini:

- Apakah tampilan website SMK Negeri Sumsel Palembang sangat menarik untuk dikunjungi? Soal ini responden rata-rata dapat menjawab dengan menemukan menu pencarian dalam waktu dibawah 5 detik.

- Apakah anda merasa puas dengan fungsi pencarian/search yang ada di website SMK Negeri Sumsel Palembang? Soal ini responden rata-rata menjawab nya dalam waktu dibawah 10 detik.

- Apakah anda anda sangat tertarik untuk mengakses menggunakan website SMK Negeri Sumsel Palembang? Soal ini responden menjawab nya dalam waktu kurang lebih dibwah 10 detik.

- Dapatkah anda memahami tampilan menu di website SMK Negeri Sumsel kembali? Soal ini responden 
menjawabnya dengan membuka kembali menu profil dalam waktu dibwah 2 detik.

- Apakah anda merasa nyaman dan ingin mengunjungi website SMK Negeri Sumsel kembali? Soal ini responden menjawab nya dalam waktu kurang dari 2 detik

Aspek efficiency seperti berikut ini:

- Apakah anda menemukan link home pada website SMK Negeri Sumsel dengan cepat? Soal ini rata-rata responden dapat menjawab nya dengan membuka link home website dalam waktu 1 Menit.

- Apakah anda melakukan proses search pencarian informasi dengan cepat pada website SMK Negeri Sumsel? Soal ini responden menjawabnya dengan mencoba mencari informasi pada web dalam waktu 1 menit.

- Apakah anda dapat melakukan login dengan cepat pada menu login di website SMK Negeri Sumsel? Soal ini responden dapat menjawab dengan baik dalam waktu kurang dari 1 menit.

- Dapatkah anda menemukan link berita dan pengumuman berita terupdate tiap hari dengan cepat? Soal ini responden dapat menjawabnya dalam waktu kurang dari 5 detik.

- Apakah anda dapat kembali ke menu sebelumnya dengan mudah dan cepat pada website SMK Negeri Sumsel? Soal ini responden dapat menjawabnya dengan mencari menu home dalam waktu kurang dari 5 detik.

Aspek memorability seperti berikut ini:

- Dapatkah anda mengingat tampilan menu dan informasi pada website SMK Negeri Sumsel? Soal ini responden dapat menjawabnya dengan membaca informasi yang ada pada website dalam waktu 2 menit.

- Apakah Anda dapat mengingat link website SMK Negeri Sumsel dengan mudah? soal ini responden dapat menjawabnya dalam waktu lebih dari 1 menit.

- Bisakah anda menemukan dan mengakses kembali menu pengumuman pada website SMK Negeri Sumsel? Soal ini responden dapat menjawabnya dalam waktu krang dari 15 detik.

- Bisakah anda menemukan dan mengakses kembali menu sebelumnya pada website SMK Negeri Sumsel? soal ini responden rata-rata menjawabnya dalam waktu kurang dari 1 menit.

- Dapatkah anda menemukan informasi berita tentang sekolah SMK Negeri Sumsel kembali? Soal ini responden dapat menjawabnya rata-rata dalam waktu kurang dari 5 detik.

Aspek error seperti berikut ini:

- Bisakah anda mengakses website SMK Negeri Sumsel dengan baik ? soal ini responden dengan melihat halaman informasi sekolah dalam waktu kurang lebih dibawah 5 detik.

- Apakah anda menemukan informasi yang diinginkan pada website SMK Negeri Sumsel dengan baik ? Soal ini responden mencari informasi yang mereka cari dalam waktu 1 menit.

- Apakah anda dapat menelusuri menu search informasi pada website SMK Negeri Sumsel dengan baik? soal ini responden dapat mengunjungi halaman pencarian dalam waktu kurang dari 10 detik.

- Dapatkah anda mengakses setiap menu yang ada di website SMK Negeri Sumsel dengan baik? soal ini responden dengan mencoba memahami website dan menjawabnya dalam waktu 10 detik.

- Bisakah anda mengakses menu home page pada website SMK Negeri Sumsel dengan baik ? Soal ini responden dapat mengunji link menu home dengan baik dalam waktu 2 detik.

Untuk memastikan jawaban responden yang telah dikemukakan dapat dipertanggung jawabkan maka dilakukan berbagai macak uji diantaranya yaitu uji validitas, uji reliabilitas dan uji koefisien. Dalam melakukan uji validitas Jika skor dari dua instrument berbeda yang mengukur konstruk yang sama mempunyai korelasi tinggi, maka perlu dilakukan validitas konvergen. Hal ini membuktikan bahwa alat ukur tersebut secara tepat mengukur konstruk yang dimaksud. Untuk menguji validitas konvergen, syarat yang digunakan untuk pemeriksaan awal skor loading adalah memenuhi level 0,5 yang dianggap signifikan secara partikal. Semakin tinggi nilai factor loading, semakin penting peranan loading dalam menginterpretasikan matrik factor. Jika skor loading $<0,5$ maka indikator dapat dihapus konstruknya karena tidak termuat (load) ke konstruk yang mewakilinya [15]. Hasil Uji validitas ditunjukkan pada Gambar outer loading.

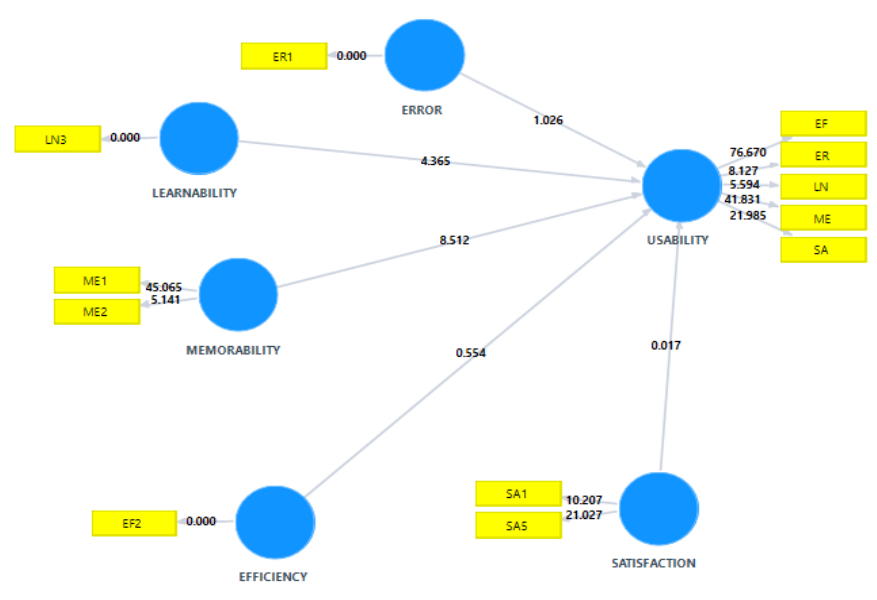

Gambar 6. Uji Validitas

Selanjutnya untuk melihat hasil uji validitas yaitu Covergent validity dianggap valid apabila nilai outer loading 
diatas 0.50 seperti yang diperlihatkan pada Gambar 7 berikut ini.

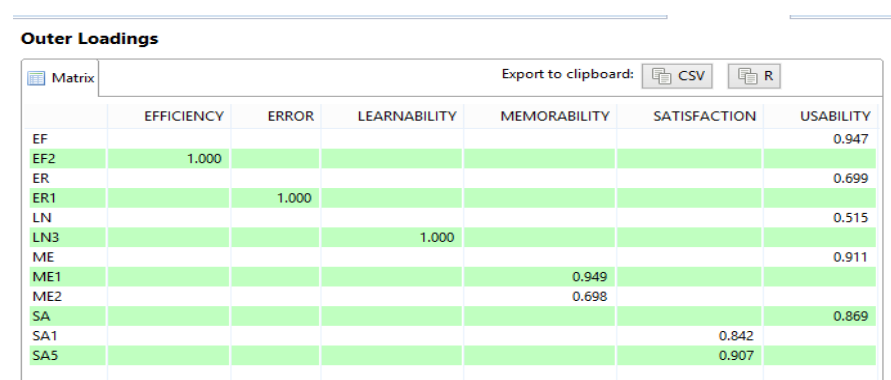

Gambar 6. Hasil Uji Validitas

Sesuai dengan Gambar 6 yaitu hasil Uji Validitas dapat dinyatakan bahwa pada output outer loadings untuk variabel EFFICIENCY $=0.947 \mathrm{EF} 2=1.000$ dinyatakan valid, variable $\mathrm{ERROR}=0.699 \quad \mathrm{ER} 1=1.000$ dinyataan valid, variable LEARNABILITY $=0.515 \mathrm{LN} 3=1.000$ dinyataan valid, variable MEMORABILITY ME1 $=0.949$ ME2 $=0.698$ dinyataan valid, variable SATISFACTION SA $1=0.842$ SA5 $=0.907$ dinyataan valid. Selanutnya adalah uji reliabilitas, uji reliabilitas dapat dilihat pada seperti pada Tabel 2 menyatakan bahwa suatu instrument penelitian dikatakan reliabel bila koefisien reliabilitas $(\mathrm{r})>0.6$ [16]. Berdasarkan keterangan Tabel 2 diketahui bahwa besarnya nilai Composite Reliability hasil dari output SmartPls pada semua variabel $>$ dari 0.7. untuk itu sesuai dengan Tabel 2 Composite Reliability dari data input SmartPls dapat dinyatakan bahwa nilai uji reliabel dari semua variabel dinyatakan reliable.

TABEL 2. COMPOSITE RELIABILITY

\begin{tabular}{|c|c|c|c|}
\hline No & Variabel & Nilai Cronbach Alpha & Keterangan \\
\hline 1 & Efficiency & 1.000 & Reliabel \\
\hline 2 & Error & 1.000 & Reliabel \\
\hline 3 & Learnability & 1.000 & Reliabel \\
\hline 4 & Memorability & 0.816 & Reliabel \\
\hline 5 & Satisfaction & 0.867 & Reliabel \\
\hline
\end{tabular}

Pengujian selanjutnya adalah pengujian koefisien, dimana pengujian ini dilakukan dengan Statistik uji: t-test; p-value $\leq$ 0.05 (alpha $5 \%$ ); signifikan [17]. Pengujian koefisien dilakukan dengan uji (t) secara parsial terhadap koefisien jalur pengaruh langsung yang tampak dalam Gambar 8.

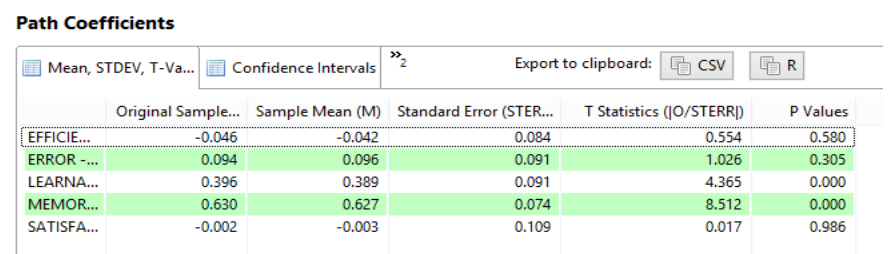

Gambar 8. Hasil Uji Koefisien

Sesuai dengan Gambar 7 dapat dijelaskan bahwa:

- Faktor Learnabilty tidak mempengaruhi usability website SMK Negeri Sumsel Palembang. Hasil analisis menunjukkan koefisien jalur pengaruh langsung adalah $\quad \mathrm{P}$. Value $=0.000 \quad$ dinyatakan signifikan. Sehingga dikatakan website SMK Negeri Sumsel Palembang sudah mudah dimengerti dan dipelajari.

- Faktor Efficiency tidak mempengaruhi usability website SMK Negeri Sumsel Palembang. Hasil analisis menunjukkan koefisien jalur pengaruh langsung adalah P.Value $=0.580$ tidak signifikan. Sehingga dikatakan website SMK Negeri sumsel belum cukup effisien untuk digunakan.

- Faktor Error mempengaruhi usability website SMK Negeri Sumsel Palembang. Hasil analisis menunjukkan koefisien jalur pengaruh langsung adalah P.Value $=0.305$ dikatakan signifikan. Sehingga dikatakan website SMK Negeri Sumsel Palembang tidak banyak terjadi kesalahan pada saat mengakses web.

- Faktor Satisfaction tidak mempengaruhi usability website SMK Negeri Sumsel Palembang. Hasil analisis menunjukkan koefisien jalur pengaruh langsung adalah P.Value $=0.986$, tidak signifikan. Sehingga dikatakan website SMK Negeri Sumsel belum cukup mudah digunakan.

- Faktor Memorability tidak mempengaruhi usability website SMK Negeri Sumsel Palembang. Hasil analisis menunjukkan koefisien jalur pengaruh langsung adalah P.Value $=0.000$, dinyatakan signifikan, Sehingga dikatakan website SMK Negeri Sumsel sudah cukup diingat kembali dalam mengakses website tersebut.

\section{KESIMPULAN}

Berdasarkan hasil penelitian yang telah dibahas dalam bab sebelumnya maka dapat disimpulkan bahwa pengukuran usability pada variabel Learnability dinyatakan sudah cukup baik, karena bagi pengguna cukup mengerti dan memahami pada saat mengunjungi situs website SMK Negeri Sumsel Palembang.

Pengukuran usability pada variabel Efficiency dinyatakan belum cukup baik, karena bagi pengguna pada saat mencari informasi yang dibutuhkan masih belum update dan cepat.

Pengukuran usability pada variabel Satisfaction dinyatakan belum cukup baik, karena sebagai pengguna ingin memakai suatu aplikasi untuk memudahkan dimana mencari informasi, bagi pengguna belum bisa menemukan informasi secara mudah.

Pengukuran usability pada variabel Memorability dinyatakan baik, karena letak menu-menu pada website tidak dilakukan perubahan, sehingga pengguna mudah mengingatnya dan mengakses home page website kembali.

Pengukuran usability pada variabel Error dinyatakan baik, karena pada saat pengguna mengakses menu-menu pada website tidak terlalu sering terjadi kesalahan. 


\section{UCAPAN TERIMA KASIH}

Terima kasih penulis sampaikan kepada tim Jurnal Sisfokom yang telah memberikan kesempatan kepada kami penulis untuk mempublikasikan artikel ini. Selain itu juga kami sampaikan banyak terima kasih kepada reviewer yang telah memberikan waktunya dalam melakukan review artikel ini sehingga kami penulis mendapatkan masukkan.

\section{REFERENSI}

[1] L. Kusworo and A. Handayanto, "Sistem Informasi Lomba Aplikasi Mobile Kihajar Berbasis Website Pada Balai Pengembangan Multimedia Pendidikan Dan Kebudayaan,”Sens 4, vol. 1, no. 1, 2019.

[2] I. Nuryanto, "Rancang Bangun Sistem Informasi Pengelolaan Proyek Dak Sekolah Dasar Berbasis Web Dan Multimedia (Studi kasus: CV. Star Norst Kab Temanggung)," Respati, vol. 8, no. 22, 2017.

[3] N. Oktaviani and F. Fatmasari, "Measuring User Perspectives on Website Conference Using System Usability Scale," J. Inf. Syst. Informatics, vol. 2, no. 2, pp. 279-290, 2020.

[4] N. Wedayanti, N. K. A. Wirdiani, and I. K. A. Purnawan, "Evaluasi Aspek Usability pada Aplikasi Simalu Menggunakan Metode Usability Testing," J. MERPATI, vol. 7, no. 2, pp. 113-124, 2019.

[5] F. Purwaningtias and U. Ependi, "Pengujian Usability Website Pondok Pesantren Qodratullah Menggunakan System Usability Scale," J. Sains dan Inform., vol. 6, no. 1, pp. 34-43, 2020.

[6] A. H. Mirza and D. Irawan, "Usability Testing of Senjang Muba Application Using System Usability Scale," J. Inf. Syst. Informatics, vol. 2, no. 2, pp. 231-245, 2020.

[7] F. Dias and A. C. R. Paiva, "Pattern-based usability testing," in 2017 IEEE International Conference on Software Testing, Verification and Validation Workshops (ICSTW), 2017, pp. 366-371.
[8] U. Ependi, T. B. Kurniawan, and F. Panjaitan, "System Usability Scale Vs Heuristic Evaluation: A Review," Simetris J. Tek. Mesin, Elektro dan Ilmu Komput., vol. 10, no. 1, pp. 65-74, 2019.

[9] B. O. Y. ALFITRI, "Evaluasi Kegunaan Sistem Informasi Akademik Universitas Abdurrab Menggunakan Metode Website Usability Evaluation.” Universitas Islam Negeri Sultan Syarif Kasim Riau, 2020.

[10] R. A. Pratama, "Evaluasi Usability Website Stmik Hangtuah Menggunakan Metode System Usability Scale." Universitas Islam Negeri Sultan Syarif Kasim Riau, 2020.

[11] P. W. Novika, "Pengaruh Penerapan SOP dan Lingkungan Kerja Terhadap Kinerja Guru di SD Negeri 001 Sekupang," J. Elektornik, vol. 2 , no. 1,2018

[12] S. Christie Soleman, "Analisa Pengaruh Application Quality terhadap E-Trust serta Implikasinya terhadap Online Booking Intentions: Telaah pada Mobile Application Airy Indonesia." Universitas Multimedia Nusantara, 2019.

[13] D. Pratiwi, M. C. Saputra, and N. H. Wardani, "Penggunaan Metode User Centered Design (UCD) dalam Perancangan Ulang Web Portal Jurusan Psikologi FISIP Universitas Brawijaya," J. Pengemb. Teknol. Inf. dan Ilmu Komput. e-ISSN, vol. 2548, p. 964X, 2017.

[14] U. Ependi, A. Putra, and F. Panjaitan, "Evaluasi tingkat kebergunaan aplikasi Administrasi Penduduk menggunakan teknik System Usability Scale," Regist. J. Ilm. Teknol. Sist. Inf., vol. 5, no. 1, pp. 63-76, 2019.

[15] R. Andespa, "Faktor-Faktor yang Mempengaruhi Minat Nasabah dalam Menabung di Bank Syariah," Al-Masraf J. Lemb. Keuang. dan Perbank., vol. 2, no. 1, pp. 43-57, 2017.

[16] F. Yusup, "Uji validitas dan reliabilitas instrumen penelitian kuantitatif," Tarb. J. Ilm. Kependidikan, vol. 7, no. 1, 2018.

[17] T. Husain and A. Budiyantara, "Analisis End-User Computing Satisfaction (EUCS) Dan WebQual 4.0 Terhadap Kepuasan Pengguna," JATISI (Jurnal Tek. Inform. dan Sist. Informasi), vol. 4, no. 2, pp. 164 176, 2018. 